\title{
KESETARAAN GENDER DALAM PRESPEKTIF UNDANG-UNDANG NOMOR 13 TAHUN 2003 TENTANG KETENAGAKERJAAN
}

\author{
Prihatin Effendi ${ }^{1}$, Devi Ratnasari ${ }^{2}$ \\ 1. Dosen Program Studi Ilmu Hukum, Fakultas Hukum, Universitas Gresik \\ 2. Mahasiswa Program Studi Ilmu Hukum, Fakultas Hukum, Universitas Gresik
}

\begin{abstract}
ABSTRAK
Penelitian ini membahas tentang Kesetaraan gender dalam perspektif Undang-Undang Nomor 13 Tahun 2003 Tentang Ketenagakerjaan, berdasarkan UU Ketenagakerjaan. Penelitian ini didasarkan pada kesetaraan gender sebagai salah satu isu di bidang ketenagakerjaan. Sehingga yang menjadi pokok dari penelitian ini ialah pengaturan kesetaraan gender dalam UU Ketenagakerjaan. Kemudian untuk menjawab pertanyaan tersebut penulis menggunakan metode penelitian hukum normatif dengan analisis yang bersifat deskriptif. Data yang di gunakan bersumber dari perundang-undangan, studi kepustakaan, dan pendapat-pendapat para sarjana. Hasil penelitian ini menunjukkan; 1) Pengaturan Kesetaraan gender dalam UU Ketenagakerjaan terdapat dalam beberapa Pasal, diantaranya Pasal 5, Pasal 6, dan Pasal 86, yang pada intinya menjelaskan bahwa Setiap tenaga kerja memiliki kesempatan yang sama tanpa diskriminasi untuk memperoleh Pekerjaan dan memperoleh perlakuan yang sama dari Pengusaha, serta mempunyai hak untuk memperoleh perlindungan atas keselamatan dan kesehatan kerja, moral dan kesusilaan; sekaligus perlakuan yang sesuai dengan harkat dan martabat manusia serta nilai-nilai agama. 2) Pada dasarnya UU Ketenagakerjaan melarang perlakuan diskriminisasi. Namun dalam pengaturan syarat kerja sering terjadi perbedaan perlakuan, permasalahan kesetaraan gender dalam dunia kerja dipengaruhi oleh faktor-faktor seperti, marginalisasi, subordinasi, stereotipe, violence, dan beban kerja. Ada beberapa upaya untuk mewujudkan keadilan dan kesetaraan gender yaitu perlunya peran serta masyarakat, lembaga swadaya masyarakat dan pemerintah pengembangan diri bagi perempuan dalam segala bidang khususnya dibidang ketenagakerjaan
\end{abstract}

\section{Kata kunci : Gender, Kesetaraan Gender, Hukum Ketenagakerjaan}

\section{a. PENDAHULUAN}

\subsection{Latar Belakang Masalah}

Perkembangan dibidang ketenagakerjaan juga membawa dampak permasalahan, masalah tenaga kerja khususnya tenaga kerja perempuan saat ini terus berkembang dan semakin kompleks mengikuti perkembangan ketenagakerjaan. Pada masa perkembangan tersebut pergeseran nilai dan tata kehidupan akan banyak terjadi, menghadapi pergeseran nilai dan tata kehidupan, pengawasaan ketenagakerjaan dituntut untuk mampu mengambil langkah- langkah antisipatif serta mampu menampung segala perkembangan yang terjadi.

Kesetaraan gender merupakan isu yang sering menjadi topik bahasan ketenagakerjaan di Indonesia. Hal disebabkan oleh adanya perbedaan perlakuan antara pekerja perempuan dengan pekerja laki-laki, bahkan seringkali pekerja perempuan dituding tidak dapat memberikan hasil yang maksimal bagi perusahaan atau bahkan dikatakan membebani perusahaan.

Berbicara mengenai pekerja perempuan, tentunya tidak dapat dimungkiri dari sudut pandang sosiologi bahwa kedudukan perempuan tidak sama dengan 
kedudukan laki-laki. Secara tidak langsung, hal ini teradopsi dalam lingkungan kerja, sehingga kedudukan perempuan seolah-olah dinomorduakan. Budaya yang kurang menghargai perempuan ini juga terdapat dalam dunia kerja. Tidak jarang perempuan mendapatkan perlakuan yang semena-mena dan hak-haknya seringkali tidak diperhatikan. Hal ini tentu menimbulkan kerugian bagi pekerja perempuan. ${ }^{1}$

Tidak dapat dipungkiri bahwa memang benar perempuan memiliki perbedaan jika dbandingkan pekerja laki-laki, misalnya pekerja perempuan membutuhkan cuti haid, melahirkan dan fasilitas menyusui, sedangkan pekerja laki-laki tidak. Namun, tidak bisa dimungkiri, perusahaan membutuhkan baik pekerja laki-laki, maupun pekerja perempuan. Pekerja perempuan mempunyai kelebihankelebihan jika dibandingkan dengan pekerja laki-laki, demikian juga sebaliknya. Dengan demikian, idealnya tidak ada perbedaan perlakuan antara pekerja laki-laki dengan pekerja perempuan oleh perusahaan.

Sehubungan dengan uraian di atas, untuk lebih mengetahui secara nyata tentang pelaksanaan UU Ketenagakerjaan. Mengingat masih banyak perusahaan, pekerja perempuan, pekerja laki-laki dan instansi pemerintahan yang berkaitan dengan ketenagakerjaan yang belum memahami sepenuhnya tentang kesetaraan gender dalam perspektif UU Ketenagakerjaan.

${ }^{1}$ Jimmy Joses Sembiring, Hak \& Kewajiban Pekerja Berdasarkan Peraturan Terbaru, Cetakan pertama, Visimedia, Jakarta, 2016, h.35

\subsection{Rumusan Masalah}

1. Bagaimana pengaturan kesetaraan gender dalam perspektif Undang-Undang Nomor 13 Tahun 2003 Ketenagakerjaan?

2. Apakah Undang-Undang Nomor 13 Tahun 2003 Tentang Ketenagakerjaan telah menjamin adanya persamaan gender dalam kesempatan mendapatkan pekerjaan?

\subsection{Tujuan Penelitian}

1. Untuk mengetahui ketentuan Kesetaraan gender dalam perspektif Undang-Undang Nomor 13 Tahun 2003 Tentang Ketenagakerjaan.

2. Untuk mengetahui apakah UndangUndang Nomor 13 Tahun 2003 Tentang Ketenagakerjaan telah menjamin adanya persamaan gender dalam kesempatan dalam mendapakan pekerjaan.

\subsection{Manfaat Penelitian}

1. Secara teoritis, untuk menambah pengetahuan penulis tentang bagaimana pengaturan kesetaraan gender dalam perspektif Undang-Undang Nomor 13 Tahun 2003 Tentang Ketenagakerjaan.

2. Secara praktis, untuk dapat memberikan sumbangan pemikirn yuridis dan masukanmasukan yang bermanfaat demi perkembangan ilmu pengetahuan terhadap kesetaraan gender dalam dunia kerja.

\section{b. TINJAUAN PUSTAKA}

\subsection{Pengertian Gender}

Gender adalah suatu konstruksi atau bentuk sosial yang sebenarnya bukan bawaan lahir sehingga dapat dibentuk atau diubah 
tergantung dari tempat, waktu / zaman, suku / ras / bangsa, budaya, status sosial, pemahaman agama, negara ideologi, politik, hukum, dan ekonomi. Oleh karenanya, gender bukanlah kodrat Tuhan melainkan. buatan manusia yang dapat dipertukarkan dan memiliki sifat relatif. Hal tersebut bisa terdapat pada laki-laki maupun pada perempuan. Sedangkan jenis kelamin (seks) merupakan kodrat Tuhan (ciptaan Tuhan) yang berlaku dimana saja dan sepanjang masa yang tidak dapat berubah dan dipertukarkan antara jenis kelamin laki-laki dan perempuan. ${ }^{2}$

Kesetaraan gender adalah seperti sebuah frase (istilah) "suci" yang sering diucapkan oleh para aktivis sosial, kaum feminis, politikus, bahkan hampir oleh para pejabat negara. Istilah kesetaraan gender dalam tataran praksis, hampir selalu diartikan sebagai kondisi 'ketidaksetaraan" yang dialami oleh para wanita. Maka istilah kesetaraan gender sering terkait dengan istilah-istilah diskriminasi terhadap perempuan, seperti; subordinasi, penindasan, kekerasan dan semacamnya. $^{3}$

Diskriminasi gender pada dasarnya adalah setiap pembedaan, penyingkiran atau pembatasan atau sebaliknya yakni pilih kasih yang dilakukan seseorang karena alasan gender, sehingga mengakibatkan penolakan pengakuan dan kebahagiaan serta penolakan keterlibatan, dan pelanggaran atas pengakuan hak asasinya dan persamaan antara lelaki dan

${ }^{2}$ Riant Nugroho, Gender Dan Strategi Pengarus-Utamanya Di Indonesia, Cet. I, Pustaka Pelajar, Yogyakarta, 2008. h. 8. ${ }^{3}$ Ratna Megawangi, Membiarkan Berbeda: Sudut Pandang Baru Tentang Relasi Gender, Mizan, Tidak menyebutkan kota, 1999, h. 19. perempuan, serta hak dasarnya dalam bidang politik, ekonomi, sosial serta budaya.

\subsection{Kesetaraan Gender dalam Undang- Undang Nomor 13 Tahun 2008 Tentang Ketenagakerjaan}

Kesetaraan gender dalam UU Ketenagakerjaan termuat dalam beberapa pasal sebagai berikut:

1. Bab III Kesempatan dan perlakuan yang sama, Pasal 5 yang berbunyi: "Setiap tenaga kerja memiliki kesempatan yang sama tanpa diskriminasi untuk memperoleh Pekerjaan"

Setiap tenaga kerja mempunyai hak dan kesempatan yang sama untuk memperoleh pekerjaan dan penghidupan yang layak tanpa membedakan jenis kelamin, suku, ras, agama, dan aliran politik sesuai dengan minat dan kemampuan tenaga kerja yang bersangkutan, termasuk perlakuan yang sama terhadap para penyandang cacat.

2. Bab III Kesempatan dan perlakuan yang sama, Pasal 6 "Setiap pekerja/buruh berhak memperoleh perlakuan yang sama tanpa diskriminasi dari Pengusaha".

Pengusaha harus memberikan hak dan kewajiban pekerja/buruh tanpa membedakan jenis kelamin, suku, ras, agama, warna kulit, dan aliran politik.

3. Bab $\mathrm{X}$ perlindungan, pengupahan, dan kesejahteraan, Bagian Kesatu Perlindungan, Paragraf 5 Keselamaan dan Kesehatan kerja, Pasal 86 ayat (1) Setiap pekerja/buruh mempunyai hak untuk memperoleh perlindungan atas :

a. keselamatan dan kesehatan kerja;

b. moral dan kesusilaan; dan 
c. perlakuan yang sesuai dengan harkat dan martabat manusia serta nilai-nilai agama.

\section{b. METODE PENELITIAN}

Penelitian ini menggunakan metode penelitian hukum normatif, yang difokuskan untuk mengkaji penelitian hukum positif yang berhubungan dengan kesetaraan gender dalam prespekif Undang-Undang Ketenagakerjaan.

Sumber bahan hukum: bahan hukum primer, Undang-undang Nomor 13 Tahun 2003 tentang Ketenagakerjaan; bahan hukum sekunder: buku-buku teks yang terkait dengan tindak pidana penghinaan dan pencemaran nama baik dan kebebasan pers; bahan hukum tersier: kamus Besar Bahasa Indonesia, Kamus Hukum, media massa, dan lain-lain sebagai penunjang.

Metode yang digunakan dalam pengolahan maupun dalam analisis data yang digunakan dalam penelitian ini adalah kuantitatif, memusatkan perhatian pada prinsip-prinsip umum yang mendasari perwujudan satu gejala yang ada dalam kehidupan manusia, atau pola-pola yang dianalisis gejala-gejala sosial budaya dengan menggunakan kebudayaan dari masyarakat yang bersangkutan untuk memperoleh gambaran mengenai pola-pola yang berlaku.

\section{c. HASIL PENELITIAN DAN PEMBAHASAN}

\subsection{Pengaturan syarat kerja}

Pada dasarnya UU Ketenagakerjaan melarang perlakuan diskriminisasi. Namun dalam pengaturan syarat kerja sering terjadi perbedaan perlakuan, contoh: pekerja perempuan dianggap pekerja lajang, usia pensiun pekerja/buruh perempuan lebih rendah dari laki-laki, kesempatan mengikuti pendidikan dan pelatihan ke luar negeri lebih diutamakan kepada pekerja/buruh laki-laki, kesempatan promosi lebih diutamakan kepada pekerja/ buruh laki-laki, penyediaan fasilitas berbeda antara pekerja/buruh laki-laki dan perempuan, pengaturan penerimaan pekerja/buruh. Oleh sebab itu untuk mencegah perlakuan diskriminasi, pengusaha menghindari pengaturan yang dapat ditafsirkan diskriminasi. ${ }^{4}$

\subsection{Permasalahan kesetaraan gender dalam dunia kerja}

Secara umum permasalahan gender dalam sektor pekerjaan dilatarbelakangi oleh adanya keyakinan gender yang keliru di tengah-tengah masyarakat. Peran gender (gender role) sebagai bentuk ketentuan sosial diyakini sebagai sebuah kodrat sehingga menyebabkan ketimpangan sosial dan hal ini sangat merugikan posisi perempuan dalam berbagai komunitas sosial baik dalam pendidikan, sosial budaya, politik dan juga ekonomi. Di sektor pekerjaan, ketidakadilan dapat saja terjadi karena hal-hal sebagai berikut.

1. Marginalisasi

Marginalisasi atau proses pemiskinan terhadap kaum perempuan banyak terjadi dalam budaya, birokrasi, di pabrik bahkan dalam program pembangunan. Misalnya saja

${ }^{4}$ Departemen Tenaga Kerja Dan Transmigrasi Republik Indonesia, Kesempatan Dan Perlakuan Yang Sama Di Indonesia (Equal Employment Opportunity), Edisi Pertama, Kantor ILO Jakarta, Jakarta, 2005, h. 60. 
karena keyakinan atau anggapan gender bahwa seorang perempuan bukanlah pencari nafkah utama keluarga, maka jika dia bekerja sesungguhnya hanya sebagai pencari tambahan belaka. Oleh karena itu perempuan yang bekerja boleh digaji lebih rendah dibanding lelaki pada posisi yang sama, karena lelaki adalah kepala rumah tangga dan pencari nafkah utama keluarga. Demikian juga, dengan hanya mengakui lelaki sebagai "kepala rumah tangga" dan "pencari nafkah utama", banyak program pertanian dan ekonomi menghalangi kaum perempuan untuk untuk mendapat pelatihan ataupun akses kredit. Demikian juga banyak jenis pekerjaan yang dianggap cocok bagi "perempuan" dinilai lebih rendah, sehingga mendapat imbalan lebih rendah juga. ${ }^{5}$

\section{Suboordinasi}

Subordinasi atau pemiskinan ekonomi yan dimaksud di sini adalah proses berhubungan dengan hal politik dan proses pengambilan keputusan dan pengendali kekuasaan. Meskipun jumlah kaum perempuan mencapai $50 \%$ dari penduduk bumi, namun posisi mereka ditentukan dan dipimpin oleh kaum lelaki. Subordinasi tersebut tidak saja secara global melainkan juga dalam birokrasi pemerintahan, dalam masyarakat maupun dalam rumah tangga. Banyak sekali kasus baik dalam tradisi, tafsiran, keagamaan, maupun dalam aturan birokrasi di mana kaum perempuan diletakkan sebagai subordinasi dari kaum lelaki. Misalnya saja buruh perempuan yang

${ }^{5}$ International Labour Organization, Buku Panduan Untuk Buruh, Apa Itu Gender?, Jakarta, 1997, h. 26-27. meskipun memiliki ketrampilan berorganisasi tidak dipilih menjadi pemimpin serikat buruh karena asumsi/anggapan bahwa perempuan itu emosional dan pemimpin serikat buruh memerlukan orang yang rasional, adalah diskriminasi gender yang mengakibatkan seorang perempuan tidak dapat menjadi pemimpin buruh. ${ }^{6}$

3. Stereotipe

Stereotip adalah satu bentuk diskriminasi dengan cara memberi "label" yang memojokkan kaum perempuan dan berakibat negatif terhadap mereka. Misalnya label kaum perempuan sebagai "ibu rumah tangga" sangat merugikan mereka jika mereka hendak aktif dalam kegiatan diluar rumah seperti kegiatan bekerja di pabrik, politik, bisnis ataupun birokrasi. Sementara label lelaki sebagai pencari nafkah" mengakibatkan apa saja yang dihasilkan oleh kaum perempuan dianggap sebagai "sambilan" atau "tambahan" dan cenderung tidak diperhitungkan. Karena label bahwa perempuan lembut dan emosional, menyulitkan mereka memasuki pasaran tenaga kerja yang dianggap hanya cocok bagi lelaki seperti bagian keamanan, mandor ataupun manajer.

\section{Violence}

Berbagai bentuk kekerasan terhadap kaum perempuan akibat perbedaan gender muncul dalam berbagai bentuk. Pertama yang bersifat fisik seperti pemerkosaan, incest/berbuat zina dengan keluarga sendiri, pemukulan dan penyiksaan, bahkan pemotongan alat genital perempuan dan lain

${ }^{6}$ Ibid. h. 26.

${ }^{7}$ Ibid. h. 27. 
sebagainya. Kedua dalam bentuk kekerasan nonfisik seperti pelecehan seksual (sexual harassment), membuat secara emosional tergantung dan lain sebagainya. ${ }^{8}$

\section{Beban Kerja}

Kalau kita lihat pada umumnya suatu rumah tangga, berapa jenis kegiatan yang dilakukan oleh lelaki dan beberapa yang dilakukan oleh perempuan, di banyak observasi menunjukkan perempuan mengerjakan hampir 90\% dari buruhan domestik. Terlebih-lebih bagi mereka yang bekerja, karena selain bekerja di tempat kerja namun juga masih harus mengerjakan pekerjaan domestik. ${ }^{9}$

\subsection{Upaya mewujudkan kesetaraan dan keadilan gender}

Terdapat beberapa upaya untuk mewujudkan keadilan dan kesetaraan gender, baik dari segi intern dan ekstern, yakni: ${ }^{10}$

1) Segi intern Dewasa ini perempuan sudah banyak yang menyadari akan pentingnya untuk memajukan diri dan berkembang dalam segala bidang. Contohnya sudah banyak perempuan yang menuntut ilmu dari pendidikan dasar sampai gelar tertinggi dalam dunia pendidikan. Dari sisi intern perempuan sendiri, banyak perempuan yang telah secara sukarela terjun di ranah politik baik dengan menjadi calon legislatif atau eksekutif di daerah maupun di pusat. Demikian pula dalam

${ }^{8}$ Ibid. h. 27-28.

${ }^{9}$ Ibid. h. 27.

${ }^{10}$ Hervina Puspitosari, Andina Elok Puri Maharani, Pengarusutamaan Gender Di Bidang Ketenagakerjaan, Vol 3, No 1 (2014), Fakultas Hukum Universitas Surakarta, 2014, h. 15-16. bidang militer, jabatan komandan dalam kesatuan juga tidak sedikit yang diduduki oleh perempuan.

2) Segi ekstern ini merupakan peran masyarakat, lembaga swadaya masyarakat dan pemerintah.

a. Masyarakat Sebagai bagian dari kelompok sosial, masyarakat telah melakukan upaya-upaya untuk menempatkan perempuan pada posisi yang sesuai dengan porsinya. Seperti dalam susunan organisasi karang taruna di desa, perempuan juga banyak yang menjadi ketua dan wakil ketua karang taruna. Demikian pula adanya organisasi Pembinaan Kesejahteraan Keluarga (PKK) desa yang di dalamnya beranggotakan ibu-ibu yang terlibat langsung dalam penyampaian aspirasi dan pengambilan keputusan atas masalah-masalah tertentu sesuai dengan lingkup PKK.

b. Lembaga Swadaya Masyarakat (LSM) Banyak LSM yang bergerak di bidang perlindungan dan peningkatan kesetaraan gender. Seperti Yayasan Perempuan Indonesia, yayasan kakak, yayasan srikandi dsb. Dalam kegiatannya, perempuan banyak dilibatkan sehingga mampu mengembangkan kemampuan intelektual dan ketrampilannya.

c. Pemerintah Presiden telah mengeluarkan Instruksi Presiden nomor 9 tahun 2000 tentang pengarusutamaan gender. Dengan adanya instruksi yang diperintahkan pada segenap departemen dan instansi khusus ini, presiden berharap agar dalam pelaksanaannya 
dapat berjalan maksimal dan tepat sasaran. Demikian pula dengan lahirnya undang-undang nomor 13 tahun 2003 tentang ketenagakerjaan. Di dalamnya mengandung perlindungan terhadap perempuan juga, khususnya dalam bidang ketenagakerjaan.

\section{e. KESIMPULAN DAN SARAN}

\subsection{Kesimpulan}

1. Pengaturan Kesetaraan gender dalam UU Ketenagakerjaan terdapat dalam beberapa Pasal, diantaranya Pasal 5, Pasal 6, dan Pasal 86, yang pada intinya menjelaskan bahwa Setiap tenaga kerja memiliki kesempatan yang sama tanpa diskriminasi untuk memperoleh Pekerjaan dan memperoleh perlakuan yang sama dari Pengusaha, serta mempunyai hak untuk memperoleh perlindungan atas keselamatan dan kesehatan kerja, moral dan kesusilaan; sekaligus perlakuan yang sesuai dengan harkat dan martabat manusia serta nilai-nilai agama.

2. Pada dasarnya UU Ketenagakerjaan melarang perlakuan diskriminisasi. Namun dalam pengaturan syarat kerja sering terjadi perbedaan perlakuan, permasalahan kesetaraan gender dalam dunia kerja dipengaruhi oleh faktor-faktor seperti, marginalisasi, subordinasi, stereotipe, violence, dan beban kerja. Ada beberapa upaya untuk mewujudkan keadilan dan kesetaraan gender yaitu perlunya peran serta masyarakat, lembaga swadaya masyarakat dan pemerintah pengembangan diri bagi perempuan dalam segala bidang khususnya dibidang ketenagakerjaan.

\subsection{Saran}

1. Diperlukan penerapan dan pengawasan terhadap UU Ketenagakerjaan dan sehingga bisa diterapkan kesetaraan gender sehingga keadilan gender terwujud di dalam bidang ketenagakerjaan..

2. Diperlukan sensitivitas gender pada semua lapisan apakah itu pengusaha industri, pemerintah, masyarakat maupun para pekerja/buruh perempuan tersebut dalam meminimalisir persoalan-persoalan bias gender di dunia kerja.

\section{DAFTAR PUSTAKA}

Jimmy Joses Sembiring, 2016, Hak \& Kewajiban Pekerja Berdasarkan Peraturan Terbaru, Cetakan pertama, Jakarta : Visimedia.

Riant Nugroho, 2008, Gender Dan Strategi Pengarus-Utamanya Di Indonesia, Cet. I, Yogyakarta : Pustaka Pelajar.

Ratna Megawangi, 1999, Membiarkan Berbeda: Sudut Pandang Baru Tentang Relasi Gender, Mizan, Tidak menyebutkan kota dan penerbit.

Departemen Tenaga Kerja Dan Transmigrasi Republik Indonesia, 2005, Kesempatan Dan Perlakuan Yang Sama Di Indonesia (Equal Employment Opportunity), Edisi Pertama, Jakarta : Kantor ILO Jakarta.

International Labour Organization, 1997, Buku Panduan Untuk Buruh, Apa Itu Gender?, Jakarta.

Hervina Puspitosari, Andina Elok Puri Maharani, 2014, Pengarusutamaan Gender Di Bidang Ketenagakerjaan, 
Vol 3, No 1 (2014), Fakultas Hukum

Universitas Surakarta. 